\title{
Pengaruh Musim Beranak Terhadap Produksi Susu Sapi Friesian Holstein (FH) di BPTSP-HMT Lembang
}

\section{The Effect of Calving Season on Milk Production of Friesian Holstein (FH) Dairy Cattle in BPTSP-HMT Lembang}

\author{
Kunaifi Wicaksana \\ Fakultas Peternakan, Universitas Tulang Bawang Lampung, Jl. Gajah Mada, Bandar \\ Lampung \\ kunaifi.wicaksana@gmail.com
}

\begin{abstract}
This research was aimed to analyze the influence of breeding season on the production of Frisian Holstein $(\mathrm{FH})$ cattle milk. This research used secondary data covering milk production data of 81 lactation $\mathrm{FH}$ cattle and seasonal data (rainfall, temperature, humidity, and THI). The data is tabulated to yield the total data of each variable. Data obtained from each observed variables were analyzed using a t-test using the SAS program. Based on t-test, the results showed no significant effect on average milk production at rainy dan dry season during lactation periods of L1, L2, and L3. Our experiment suggested that season of calving showed no differences on milk production of FH dairy cattle during lactation periods of L1, L2, and L3. Conclusions in this research show that seasonal differences do not affect the diversity of milk production.
\end{abstract}

Keywords: dry season, Friesian Holstein, milk production, rainy

\section{PENDAHULUAN}

Sapi perah merupakan ternak perah utama yang memasok dan memenuhi kebutuhan susu segar maupun susu olahan masyarakat di dunia. Sapi perah yang banyak dikembangkan di Indonesia adalah sapi FH. Sapi FH merupakan sapi yang memiliki produktivitas tinggi (produksi susu). Akan tetapi produksi susu sapi FH ini masih rendah disebabkan oleh beberapa faktor salah satunya adalah musim beranak. Upaya untuk meningkatkan produksi susu sapi $\mathrm{FH}$ adalah mengetahui musim terbaik untuk mengawinkan sapi betina.

Indonesia memiliki dua musim yaitu musim hujan dan kemarau. Berdasarkan dengan ketetapan BMKG yaitu musim hujan dan musim kemarau dibedakan dari banyaknya curah hujan. BMKG mengeluarkan aturan bahwa untuk permulaan musim hujan, jumlah curah hujan dalam satu dasarian (10 hari) sama atau lebih dari 50 milimeter dan diikuti oleh beberapa dasarian berikutnya. Sedangkan untuk musim kemarau, jumlah curah hujan dalam satu dasarian (10 hari) kurang dari 50 milimeter dan diikuti oleh beberapa dasarian berikutnya. Pada umumnya sewaktu matahari berada di belahan bumi selatan dari bulan oktober sampai maret, curah hujan akan lebih banyak dibandingkan sewaktu matahari berada di belahan bumi utara dari bulan april sampai september (Distan, 2014). Sapi-sapi perah yang beranak pada musim 
hujan, produksi susunya selama 10 bulan laktasi secara kuantitatif terlihat lebih rendah dibandingkan dengan yang beranak dimusim kemarau. Rendahnya produksi susu sapi-sapi perah yang beranak di musim hujan tersebut, diduga disebabkan oleh tingginya kadar air hijauan yang dikonsumsi sehingga konsumsi bahan kering secara keseluruhan rendah dan tingginya kelembaban udara (Mukhtar, 2006) Menurut Yani dan Purwanto (2006), sapi-sapi perah di Indonesia adalah sapi FH yang memiliki iklim sedang (temperate) dengan kisaran suhu termonetral dan sifat produksi terbaik dengan suhu lingkungan $13-25^{\circ} \mathrm{C}$ dan kelembaban $55 \%$. THI yang melewati ambang batas kritis dari 72 menunjukkan bahwa sapi perah mengalami stres panas ringan $(72 \leq T H I \leq 79)$, stres sedang $(80 \leq T H I \leq 89)$ dan stres berat $(90 \leq T H I \leq 97)$ yang dapat menyebabkan penurunan produksi susu sapi perah (Bohmanova et al., 2007).

Upaya peningkatan produktivitas sapi FH tidak cukup hanya dengan perbaikan manajemen pemeliharaan dan pakan, tetapi perlu dilakukan peningkatan efektifitas perkawinan dengan cara mengetahui musim terbaik sapi betina dikawinkan. Evaluasi mengenai pengaruh musim beranak terhadap produksi susu dan reporoduksi sapi perah belum banyak dilakukan, sehingga perlu dilakukan penelitian untuk melihat pengaruh musim beranak terhadap produksi susu. Penelitian ini diharapkan dapat menjadi referensi terkini terkait musim kawin terbaik agar produksi susu yang dihasilkan optimal.

\section{METODOLOGI PENELITIAN}

\section{Metode Penelitian}

Penelitian dilakukan di Balai Pengembangan Ternak Sapi Perah dan Hijauan Makanan Ternak (BPTSP-HMT) berada di Desa Cikole Kecamatan Lembang Kabupaten Bandung Barat pada bulan Oktober sampai dengan Desember 2017.

Data yang digunakan dalam penelitian ini berupa data sekunder meliputi data beranak, data produksi susu, dari BPTSP-HMT Lembang dengan total 81 ekor sapi $\mathrm{FH}$. dan data iklim dari BMKG Bogor yakni (curah hujan, suhu (Ta), kelembaban $(\mathrm{RH})$, dan THI) tahun 2011-2017. Data beranak yakni catatan tanggal sapi betina melahirkan pertama dan tanggal melahirkan berikutnya. Data produksi susu yakni hasil pemerahan susu yang diperoleh dari pencatatan pemerahan pagi dan sore hari sebagai produksi susu harian (dalam $\mathrm{kg}$ ). Data iklim yakni data bulanan curah hujan $\left(\mathrm{mm}^{2}\right)$, $\mathrm{Ta}\left({ }^{\circ} \mathrm{C}\right), \mathrm{RH}(\%)$, dan $\mathrm{THI}$ sebagai cerminan iklim pada saat sapi $\mathrm{FH}$ beranak.

\section{Alat dan Bahan}

Data sekunder ditabulasikan menggunakan Microsoft Excel 2010 sedangkan analisis data menggunakan Software SAS 9.2 dan Minitab 16.

Bahan yang digunakan dalam penelitian ini berupa 81 ekor sapi $\mathrm{FH}$. Materi yang digunakan terdiri dari data produksi susu (total produksi susu per laktasi), data reproduksi (CI, S/C, dan DO) dari BPTSP-HMT Lembang dan data iklim (curah hujan, suhu, kelembapan, dan THI) tahun 2011-2017 dari BMKG Bogor sebagai BMKG pusat di provinsi Jawa Barat.

\section{Analisis Data}

Data tersebut kemudian ditabulasikan untuk menghasilkan data total masingmasing serta dilakukan analisis parameter iklim dengan menghitung rataan curah 
hujan, suhu udara, kelembaban udara, dan THI (Temperature Humidity Index) per bulan kemudian data tersebut dianalisis secara deskriptif. Musim dibagi menjadi dua yakni musim hujan (oktober-maret) dan musim kemarau (april-september). Penghitungan data menggunakan program SAS (Statistical Analysis System) dan minitab 16.

Analisis data yang digunakan antara lain analisis deskriptif dan uji Beda (Uji-t) meliputi musim beranak, produksi susu, data iklim. Analisis deskriptif dihitung berdasarkan Walpole (1992) sebagai berikut:

$$
\bar{X}=\sum_{i=1}^{n} X i=\frac{\mathrm{X}_{1}+\mathrm{X}_{2}+\ldots+\mathrm{X}}{\mathrm{n}}
$$

Keterangan :

$X \quad$ : rata-rata

Xi : ukuran ke-i dari peubah $\mathrm{x}$

$\mathrm{n} \quad$ : jumlah sampel

Rumus perhitungan simpangan baku sebagai berikut:

$$
S=\sqrt{\frac{\sum_{i=1}^{n}\left(x_{i}-\bar{x}\right)^{2}}{n-1}}
$$

Keterangan :

S : simpangan baku

$\mathrm{X}$ : rata-rata

Xi : ukuran ke-i dari peubah $\mathrm{x}$

n : jumlah sampel

Analisis Uji-t dilakukan untuk melihat perbedaan produksi susu, dan data iklim (curah hujan, $\mathrm{Ta}, \mathrm{RH}$, dan $\mathrm{THI}$ ) pada musim beranak yang berbeda. Dilakukan perbandingan berdasarkan musim hujan dan musim kemarau. Analisis ini menggunakan bantuan aplikasi SAS 9.2. Analisis Uji-t juga dilakukan untuk melihat pengaruh musim beranak terhadap produksi susu (Walpole 1995).

\section{HASIL PENELITIAN}

\section{Gambaran Iklim}

Hasil pengamatan iklim (curah hujan, $\mathrm{Ta}, \mathrm{RH}, \mathrm{THI}$ ) pada musim yang berbeda disajikan pada Tabel 1.

Wilayah Indonesia yang beriklim tropis memiliki dua musim yaitu musim hujan dan kemarau. Pengaruh musim terhadap produksi susu sapi perah menurut Valtorta (2006) dapat dilihat pada empat hal, yaitu: a) pengaruh pada ketersediaan dan harga bijian pakan sapi perah, b) pengaruh pada produksi dan kualitas pastura dan hijauan pakan sapi perah, c) perubahan pada penyebaran hama dan penyakit sapi perah, dan d) pengaruh langsung dari iklim dan kondisi yang ekstrim pada kesehatan, pertumbuhan dan reproduksi sapi perah. Berdasarkan hasil pengamatan curah hujan, rataan suhu, kelembaban udara dengan THI di BPTSP-HMT Lembang pada bulan 
Januari sampai bulan Desember 2011-2017 dapat diketahui bahwa rataan curah hujan pada musim hujan sebesar $245 \pm 93.31 \mathrm{~mm} /$ bulan dengan rataan suhu udara sebesar $21.01 \pm 1.82{ }^{\circ} \mathrm{C}$, rataan kelembaban udara $82.44 \pm 6.38 \%$, dan rataan $\mathrm{THI}$ sebesar 62.50 \pm 1.82 . Rataan curah hujan pada musim kemarau sebesar $131 \pm 115 \mathrm{~mm} / \mathrm{bulan}$ dengan rataan suhu udara sebesar $20.14 \pm 0.81^{\circ} \mathrm{C}$, rataan kelembaban udara $82.46 \pm 7.32 \%$, dan rataan THI sebesar $61.64 \pm 0.82$.

Rataan curah hujan, suhu udara, kelembaban udara, dan THI pada musim hujan dan kemarau berbeda. Pada musim hujan rataan curah hujan dan suhu udara lebih tinggi dibandingkan pada musim kemarau sedangkan rataan kelembaban lebih tinggi pada musim kemarau sesuai pada Tabel 1.

Tabel 1. Rataan curah hujan, Ta, RH, dan THI di BPTSP-HMT Lembang pada musim hujan dan kemarau

\begin{tabular}{lrlrl}
\hline Karakteristik & \multicolumn{3}{l}{ Hujan } & Kemarau \\
\cline { 2 - 5 } & $\mathbf{N}$ & Rataan \pm SD & $\mathbf{N}$ & Rataan \pm SD \\
\hline Curah hujan $\left(\mathrm{mm}^{2}\right)$ & & & \\
L1 & 20 & $252 \pm 126.00 \mathrm{a}$ & 29 & $122 \pm 106 \mathrm{~b}$ \\
L2 & 18 & $260 \pm 96.83 \mathrm{a}$ & 11 & $111 \pm 132 \mathrm{~b}$ \\
L3 & 3 & $224 \pm 57.11 \mathrm{a}$ & 8 & $159 \pm 107 \mathrm{a}$ \\
Rataan & $245 \pm 93.31$ & & $131 \pm 115$ \\
\hline Ta ( $\left.{ }^{\circ} \mathrm{C}\right)$ & & & \\
L1 & & & 29 & $20.11 \pm 0.65 \mathrm{~b}$ \\
L2 & 20 & $20.96 \pm 1.90 \mathrm{a}$ & 11 & $20.06 \pm 0.56 \mathrm{a}$ \\
L3 & 18 & $21.73 \pm 3.10 \mathrm{a}$ & 8 & $20.26 \pm 1.22 \mathrm{a}$ \\
Rataan & 3 & $20.33 \pm 0.45 \mathrm{a}$ & & $20.14 \pm 0.81$ \\
\hline RH (\%) & $21.01 \pm 1.82$ & & \\
L1 & & & \\
L2 & 20 & $82.00 \pm 7.43 \mathrm{a}$ & 29 & $83.44 \pm 6.01 \mathrm{a}$ \\
L3 & 18 & $81.77 \pm 7.55 \mathrm{a}$ & 11 & $79.90 \pm 8.87 \mathrm{a}$ \\
Rataan & 3 & $83.56 \pm 4.17 \mathrm{a}$ & 8 & $83.87 \pm 7.08 \mathrm{a}$ \\
\hline THI & & $82.44 \pm 6.38$ & & $82.46 \pm 7.32$ \\
L1 & & & \\
L2 & 20 & $62.45 \pm 1.90 \mathrm{a}$ & 29 & $61.61 \pm 0,66 \mathrm{~b}$ \\
L3 & 18 & $63.23 \pm 3.10 \mathrm{a}$ & 11 & $61.55 \pm 0.58 \mathrm{a}$ \\
Rataan & 3 & $61.83 \pm 0.45 \mathrm{a}$ & 8 & $61.76 \pm 1.23 \mathrm{a}$ \\
\hline
\end{tabular}

Keterangan: $\mathrm{CH}$ : Curah hujan dalam bulan, Ta: Suhu dalam bulan, $\mathrm{RH}$ : Kelembaban dalam bulan, THI: temperature humidity index dalam bulan; L1: laktasi satu, L2: laktasi dua, L3: laktasi tiga; N: jumlah ternak; huruf yang sama pada baris yang sama menunjukkan tidak berbeda nyata pada taraf uji 5\% (uji Duncan).

Hasil analisis Uji-t menunjukkan bahwa rataan curah hujan, suhu, dan THI pada laktasi pertama (L1) di musim hujan dan musim kemarau berbeda nyata $(\mathrm{p}<0.05)$, curah hujan pada rataan $\mathrm{L} 2$ di musim hujan dan kemarau berbeda nyata, sedangkan rataan pada L3 curah hujan, L2 dan L3 suhu, kelembaban, dan THI tidak berbeda nyata. Perbedaan rataan curah hujan di L1 pada musim hujan dan kemarau sebesar $130 \mathrm{~mm}$. Rataan curah hujan L1 pada musim hujan sebesar $252 \mathrm{~mm}$ sedangkan pada musim kemarau sebesar $122 \mathrm{~mm}$. Perbedaan rataan curah hujan L2 
pada musim hujan dan kemarau sebesar 149 dengan rataan curah hujan pada musim hujan sebesar $260 \mathrm{~mm}$ sedangkan pada musim kemarau sebesar $111 \mathrm{~mm}$.

Perbedaan suhu udara di BPTSP-HMT Lembang pada L1 di musim hujan dan kemarau sebesar $0.85^{\circ} \mathrm{C}$. Rataan suhu udara $L 1$ pada musim hujan sebesar $20.96^{\circ} \mathrm{C}$ sedangkan pada musim kemarau sebesar $20.11^{\circ} \mathrm{C}$. Perbedaan rataan $\mathrm{THI}$ pada $\mathrm{L} 1$ di musim hujan dan kemarau sebesar 0.84 dengan rataan THI L1 pada musim hujan sebesar 62.45 sedangkan pada musim kemarau sebesar 61.61 .

Rataan suhu udara pada musim hujan sebesar $21.01^{\circ} \mathrm{C}$ dan pada musim kemarau sebesar $20.14^{\circ} \mathrm{C}$. Rataan suhu udara di BPTSP-HMT Lembang berada pada kisaran normal suhu udara yang nyaman untuk sapi perah, Menurut Yani dan Purwanto (2006) bahwa penampilan produksi terbaik untuk bangsa sapi perah Friesian Holstein akan dicapai pada suhu lingkungan $13-25^{\circ} \mathrm{C}, 15-18^{\circ} \mathrm{C}$ (Berman 2005), 4-25 ${ }^{\circ} \mathrm{C}$ (Yousef 1985), dan suhu kritis untuk sapi perah $\mathrm{FH}$ adalah $27^{\circ} \mathrm{C}$ (Hadisutanto 2008). Sapi perah yang berada pada suhu kritis akan mengalami stres, sehingga sapi perah akan melakukan upaya penyesuaian secara fisiologis yang dapat menyebabkan peningkatan frekuensi pernafasan, denyut nadi dan suhu tubuh serta penyesuaian tingkah laku sapi perah untuk menjaga keseimbangan panas dalam tubuh.

Rataan kelembaban udara pada musim hujan sebesar $82.44 \%$ dan kemarau sebesar $82.46 \%$ yang berada diatas kisaran normal dalam pemeliharaan sapi perah sehingga dapat mempengaruhi jumlah produksi susu yang dihasilkan. Berman (2005) menyatakan bahwa kelembaban ideal untuk sapi perah 55\%, 60-80\% (Soetarno, 2003). Dalam pemeliharaan sapi perah dibutuhkan lingkungan dengan suhu dan kelembaban yang ideal untuk sapi perah, karena suhu dan kelembaban lingkungan dapat menyebabkan stres panas pada sapi perah yang menyebabkan beberapa perubahan dalam tubuh sapi perah seperti keseimbangan air dan energi (Esmay, 1982).

Rataan nilai THI pada musim hujan dan kemarau di BPTSP-HMT Lembang berada pada kisaran ideal untuk pemeliharaan sapi perah. Rataan THI di BPTSP-HMT Lembang pada musim hujan sebesar 62.50 dan musim kemarau sebesar 61.64. Nilai THI di BPTSP-HMT Lembang dapat dijadikan sebagai indikator dalam pemeliharaan sapi perah untuk mengetahui tingkat kenyamanan dan cekaman atau stres panas yang dialami sapi perah. Sapi perah yang mengalami cekaman atau stres panas dapat mengalami penurunan asupan energi yang tersedia dalam tubuh yang pada umumnya digunakan untuk fungsi produksi dan reproduksi, sehingga produksi susu dan reproduksi sapi perah dapat terganggu. Menurut Nugroho et al., (2010) bahwa Temperature Humidity Index (THI) merupakan interaksi antara suhu dan kelembaban udara yang dapat mempengaruhi kenyamanan hidup sapi perah. Sapi perah bangsa Friesian Holstein akan nyaman dan dapat menghasilkan susu dengan optimal jika berada pada THI dibawah 72. Neil (2008) menyatakan bahwa apabila nilai THI $72 \leq$ THI $\leq 79$ maka sapi akan mengalami stres ringan, nilai THI $80 \leq T H I \leq 89$ sapi akan mengalami stres sedang, dan nilai $\mathrm{THI} 90 \leq \mathrm{THI} \leq 97$ maka sapi akan mengalami stres berat.

\section{Gambaran Produksi Susu}

Analisis gambaran produksi susu hasil penelitian disajikan pada Tabel 2. Produksi susu per periode laktasi setiap ekor sapi laktasi dipengaruhi banyak faktor 
seperti kemampuan genetik, umur berproduksi, paritas, frekuensi pemerahan, lama laktasi dan status fisiologis ternak. Produksi susu dari suatu peternakan dipengaruhi oleh kapasitas produksi ternak serta kondisi keseluruhan peternakan. Oleh karena itu, produksi susu yang dihasilkan akan ditentukan oleh struktur ternak, pakan, musim, manajemen dan keseluruhan lingkungan pemeliharaan (ENTING et al., 1997).

Tabel 2. Rataan produksi susu sapi FH di BPTSP-HMT Lembang pada musim hujan dan kemarau

\begin{tabular}{lllll}
\hline $\begin{array}{l}\text { Periode } \\
\text { laktasi }\end{array}$ & $\begin{array}{l}\text { Hujan } \\
\mathbf{n} \text { (ekor) }\end{array}$ & $\begin{array}{l}\text { Produksi susu } \\
\text { (kg/ekor/laktasi) } \\
\text { (Rataan } \pm \text { SD) }\end{array}$ & $\begin{array}{l}\text { Kemarau } \\
\text { n (ekor) }\end{array}$ & $\begin{array}{l}\text { Produksi susu } \\
\text { (kg/ekor/laktasi) } \\
\text { (Rataan } \pm \text { SD) }\end{array}$ \\
\hline L1 & 20 & $3777 \pm 1174 a$ & 29 & $3934 \pm 967 a$ \\
L2 & 18 & $3829 \pm 771 \mathrm{a}$ & 11 & $4001 \pm 715 \mathrm{a}$ \\
L3 & 3 & $4002 \pm 774 a$ & 8 & $3860 \pm 1112 \mathrm{a}$ \\
\hline Rataan & $3869 \pm 906$ & & $3931 \pm 931$ \\
\hline
\end{tabular}

Keterangan: L1: laktasi satu, L2: laktasi dua, L3: laktasi tiga, n: jumlah ternak; huruf yang sama pada baris yang sama menunjukkan tidak berbeda nyata pada taraf uji $5 \%$ (uji Duncan).

Hasil analisis rataan produksi susu sapi perah $\mathrm{FH}$ pada musim hujan periode laktasi pertama (L1), laktasi kedua (L2), dan laktasi ketiga (L3) berturut-turut adalah 3 777, 3 829, dan $4002 \mathrm{~kg} / \mathrm{ekor} / \mathrm{laktasi}$. Produksi susu di musim kemarau pada periode laktasi L1, L2, dan L3 adalah 3 934, 4 001, dan 3860 kg/ekor/laktasi. Rataan keseluruhan produksi susu pada L1, L2, dan L3 musim hujan tahun 2011-2017 di BPTSP-HMT Lembang sebanyak 3869 dan pada musim kemarau 3931 kg/ekor/laktasi.

Hasil penelitian ini menunjukkan produksi susu pada musim hujan dan kemarau selama periode laktasi L1, L2, dan L3 tidak berbeda nyata $(P>0.05)$. Hal tersebut menunjukkan bahwa perbedaan musim hujan dan kemarau tidak menyebabkan perbedaan secara nyata pada produksi susu sapi perah FH di BPTSPHMT Lembang. Hal ini dikarenakan balai sudah menerapkan sistem pemeliharaan intensif artinya balai memberikan pakan hijauan dengan kuantitas yang telah terstandard, baik pada musim hujan maupun pada musim kemarau, sehinga faktor musim hujan yang dapat mempengaruhi ketersediaan hijauan tidak mempengaruhi produksi susu di BPTSP-HMT Lembang. Rataan produksi susu tertinggi pada L3 di musim hujan dengan rataan produksi susu 4002 kg/ekor/laktasi. Produksi susu sapi perah FH di BPTSP-HMT Lembang pada musim hujan periode laktasi pertama (L1) lebih rendah dibandingkan produksi susu pada L1 musim kemarau dengan selisih produksi susu sebesar $157 \mathrm{~kg} / \mathrm{ekor} / \mathrm{laktasi}$, walaupun musim hujan pada L1 merupakan musim yang baik untuk pemeliharaan dan pengembangan sapi FH dilihat dari curah hujan dan THI yang ada di lingkungan BPTSP-HMT dengan curah hujan sebesar $252 \mathrm{~mm}$ dan nilai THI 62.45. Pada musim hujan L2 produksi susu pada musim hujan lebih rendah dibandingkan L2 musim kemarau dengan selisih produksi susu sebesar 172 kg/ekor/laktasi. Produksi susu pada L3 musim hujan lebih tinggi 142 $\mathrm{kg} / \mathrm{ekor} / \mathrm{laktasi}$ dibandingkan produksi susu L3 pada musim kemarau.

Pada periode laktasi kedua (L2) musim hujan terjadi peningkatan produksi susu dari 3777 menjadi 3829 kg/ekor/laktasi yaitu meningkat sebanyak 52 
kg/ekor/laktasi. Produksi susu pada musim hujan periode laktasi ketiga (L3) mengalami kenaikan dari L2 yaitu dari 3829 menjadi 4002 kg/ekor/laktasi dengan peningaktan sebesar $173 \mathrm{~kg} / \mathrm{ekor} / \mathrm{laktasi}$. Peningkatan produksi susu di musim hujan pada L2 dan L3 dapat disebabkan oleh beberapa faktor musim dan faktor manajemen pemeliharaan seperti jumlah dan kualitas pakan yang diberikan. Menurut Pasaribu (2015) bahwa peningkatan produksi susu pada musim hujan dapat dipengaruhi oleh suhu, kelembaban, curah hujan, THI lingkungan peternakan, pemberian pakan, perubahan mutu genetik sapi perah dan perubahan tatalaksana pemeliharaan.

Produksi susu sapi perah pada musim kemarau periode laktasi kedua (L2) mengalami kenaikan dari 3934 kg/ekor/laktasi pada L1 menjadi 4001 kg/ekor/laktasi pada L2. Pada L3 produksi susu mengalami penurunan sebesar $141 \mathrm{~kg} / \mathrm{ekor} / \mathrm{laktasi}$ yaitu dari 4001 pada L2 menjadi 3860 kg/ekor/laktasi. Penurunan produksi susu sapi perah pada periode L3 musim kemarau dapat disebabkan pengaruh iklim seperti suhu, kelembaban, dan THI yang meningkat. Menurut Siregar (1996) bahwa produksi susu sapi perah yang mengalami penurunan dapat disebabkan pengaruh iklim seperti suhu rataan harian yang relatif panas yang berakibat pada penurunan konsumsi pakan.

\section{KESIMPULAN}

Perbedaan musim beranak belum mampu mempengaruhi keragaman produksi susu sapi FH pada semua periode laktasi.

\section{DAFTAR PUSTAKA}

Berman A. 2005. Estimates of heat stress relief needs for Holstein dairy cows. J Anim Sci. 83:1377-1384.

Bohmanova J, Misztal I, Cole JB. 2007. Temperaturehumidity indices as indicators of milk production losses due to heat stress. J Dairy Sci. 90:1947-1956.

[DISTAN] Dinas Pertanian Pemerintahan Kabupaten Buleleng.2014. Kemarau basah [internet].[diacu 29 mei 2018] Tersedia dari: http://www.distan.bulelengkab.go.id/artikel/kemarau-basah-13/index.html.

Enting H, Kooji D, Dijkhuizen AA, Huirne RBM, Noordhuizen-Stasses EN. 1997. Economic losses due to clinical lameness in dairy cattle. J Livestock Prod Sci. 49: $259-267$.

Esmay ML. 1982. Principle Of Animal Environment. Avi Publishing Company. Inc. Wesport, Conecticut.

Hadisutanto, B. 2008. Study on several reproductive performance of various parties in days open formulating of Fries Holland dairy cows (case in rural dairy farm, Lembang,West Bandung).

http://disertasibambang.com/2008/10/html. [Diakses 17 Mei 2018].

[Disertasi].

Mukhtar A. 2006. Ilmu Produksi Ternak Perah. Cetakan 1. Solo (ID): Sebelas Maret Univ $\mathrm{Pr}$

Neil B. 2008. Tips for keeping dairy cows cool. Regional Extension Educator-DairyUniversity of Minnesota Extension Service. 
Nugroho KAT, Surjowardojo P, Ihsan MN. 2010. Penampilan produksi sapi perah Friesian Holstein (FH) pada berbagai paritas dan bulan laktasi di ketinggian tempat yang berbeda. JIIPB. 20(1):55-64.

Pasaribu A, Firmansyah, Nahri I. 2015. Analisis faktor-faktor yang mempengaruhi produksi susu sapi perah di Kabupaten Karo Provinsi Sumatera Utara. JIIP. 18(1): 28-35.

Siregar SB. 1996. Sapi Perah, Jenis, Teknik Pemeliharaan dan Analisis Usaha. Jakarta (ID): Penebar Swadaya.

Valtorta SE. 2006. Animal production in changing climat. http://www.asrc.agri.missouri.edu. [Diakses 20 April 2018].

Walpole RE.1995. Pengantar Statistik Edisi 3 Alih Bahasa Bambang Sumantri. Jakarta (ID): Gramedia Pustaka Utama.

Walpole, RE. 1992. Pengantar Statistika.Jakarta (ID): PT Gramedia.

Yani A, Purwanto BP. 2006. Pengaruh iklim mikro terhadap respons fisiologis sapi peranakan Fries Holland dan modifikasi lingkungan untuk meningkatkan produktivitasnya (ulasan). J Med Pet 1:35-46.

Yousef MK. 1985. Thermoneutral Zone. In: M.K. Yousef (Ed.). Stress Physiology of Livestock. CRC Press, Inc. Boca Raton, Florida. 2 : 68-69. 